\title{
Microbial load in instrument used in surgeries classified as clean
}

\author{
FMG Pinto $^{1 *}$, GADA Moriya ${ }^{1,2}$, KU Graziano $^{1}$ \\ From International Conference on Prevention \& Infection Control (ICPIC 2011) \\ Geneva, Switzerland. 29 June - 2 July 2011
}

\section{Introduction / objectives}

The number of orthopedic surgery, especially surgery of total hip and knee, have been more frequent due to technological advances. This study aims to determine the microbial load in the instruments used in clean surgeries, quantifying and identifying the genus and species of microbial growth.

\section{Methods}

Orthopedic surgical instruments were immersed, after use, in sterile water, sonicated in ultrasonic washer and consecutively shaken. Then, the lavage was filtered through a $0.45 \mathrm{micron}$ membrane, the result was incubated in aerobic medium, anaerobic medium and medium for fungi and yeasts.

\section{Results}

In clean surgeries, results showed that $47 \%$ of used instruments had microbiological growth in the range of 1 to $100 \mathrm{CFU} /$ instrument. The most prevalent organism was Staphylococcus coagulase negative (28\%), followed by Bacillus subtilis (11\%).This study refuted the hypothesis that clean surgeries happen in micro-organismsfree surgery field.

\section{Conclusion}

The microbiological findings reinforce the importance of antibiotic prophylaxis, practice already well established for this category of surgical procedure.

'Departamento de Enfermagem Médico-Cirúrgica, Nursing School University of Sao Paulo, Brazil

Full list of author information is available at the end of the article

\section{Disclosure of interest}

None declared.

\section{Author details}

'Departamento de Enfermagem Médico-Cirúrgica, Nursing School University of Sao Paulo, Brazil. ${ }^{2}$ CSSD, Hospital Alemão Oswaldo Cruz, São Paulo, Brazil.

Published: 29 June 2011

doi:10.1186/1753-6561-5-S6-P313

Cite this article as: Pinto et al:: Microbial load in instrument used in surgeries classified as clean. BMC Proceedings 2011 5(Suppl 6):P313.
Submit your next manuscript to BioMed Central and take full advantage of:

- Convenient online submission

- Thorough peer review

- No space constraints or color figure charges

- Immediate publication on acceptance

- Inclusion in PubMed, CAS, Scopus and Google Scholar

- Research which is freely available for redistribution

Submit your manuscript at www.biomedcentral.com/submit

\section{() Biomed Central}

